\title{
Cross-Cultural Study of Students' Response to Education Dissatisfaction: An Australian Context
}

\author{
-Linda Newsome: Arizona State University, USA \\ Mary Helou: Macquarie University, Australia \\ Christopher Crismon: University of Phoenix, USA
}

\begin{abstract}
The inevitability and unpredictability of service failures can result in consumer dissatisfaction, whereby consumers respond to their lack of satisfaction with the service provision in a variety of ways. Previous research indicates that consumers' response options to service dissatisfaction is related to various facets of customer loyalty, which, in turn, may heavily impact on future repurchase intentions (Helou and Caddy, 2007). Accordingly, this study investigates the impact of loyalty and its cultural understanding on dissatisfaction response styles of university students. In particular, it compares the variations in response options between Anglo-Saxon Australian students and international Asian Chinese students, in an attempt to explore the impact of culture on dissatisfaction, and the resultant response options chosen by students, as guided by culturally defined perceptions and values (Helou, 2005; Helou and Caddy, 2007; Newsome and Cooper, 2016). Findings indicate that there are significant variations in terms of the degrees of ethnic loyalty and the response options engaged in as a reaction to dissatisfaction, mostly attributable to differences in cultural values. The contributions of this study are three-fold. First, the current research study further develops our understanding of cultural loyalty and its impact on students' future repurchase intentions. Secondly, it provides an understanding of the dissatisfaction response styles of university students coming from different ethnic backgrounds. Finally, the current study further contributes to our understanding of the relationship between students' ethnic backgrounds and their respective repurchase decisions.
\end{abstract}

Key words: Post-purchase dissatisfaction, Loyalty, Cultural loyalty, Student dissatisfaction, Repurchase intentions, Repurchase decisions, Education, Cross-cultural analysis, Educational services.

International Journal of Educational Studies

Vol. 2, No.2, pp. 44-52

2019

DOI: $10.53935 / 2641-533 x . v 2 i 2.24$

Corresponding Author: Linda Newsome Email: linda.newsome@asu.edu Funding: This study received no specific financial support. financial support.

Article History:

Received: 21 January 2019

Revised: 15 February 2019

Accepted: 25 March 2019

(C) 2019 by the authors; licensee Academic Publishing Group

\section{Introduction}

As consumers' response to service dissatisfaction is associated with feelings of loyalty (Hirschman, 1970), and repurchase intentions; dissatisfaction has become a significant area of research among consumer behaviourists (Singh, 1988; Day, 1980; Day and Ladon, 1977). To study the impact of cultural loyalty on students' behaviour given post-consumption dissatisfaction within the context of tertiary education, the current study is structured into six sections. The first section provides an exploration of the behavioural and non-behavioural responses to consumer dissatisfaction, and evaluates the relationship between service dissatisfaction and repurchase intentions and decisions, mainly through the use of Hirschman's (1970) typology involving loyalty-related response. The second section provides a review of the representative literature relating to the manner in which loyalty manifests itself, the antecedents of service quality, service 
dissatisfaction response styles and cultural perceptions of loyalty; while the third section elaborates on the research method used to explore the impact of cultural loyalty on students' dissatisfaction responses. This is followed by a presentation of the research outcomes, and a discussion of the findings related to the relationship between the degree of tertiary education service satisfaction/dissatisfaction, cultural loyalty, and post-purchase and post-consumption dissatisfaction response. Finally, the current study concludes with a provision of a summary of the main research issues of study, namely the impact of loyalty on the AngloSaxon Australian and the international Asian Chinese students' post-purchase recovery in the context of tertiary education, and ends with the provision of salient directions and avenues for future research.

Earlier research indicated that consumers faced with dissatisfaction respond in any one of three ways: Exit, referring to the termination of the buyer-seller relationship and switching to a competitor's product; voice, denoting the communication of their dissatisfaction; or loyalty, as witnessed by the silence and lack of action (Hirschman, 1970). Since then, many researchers have further explored the classifications of consumer responses to dissatisfaction, all reaching an understanding that consumers either engage in a behavioural response which requires active actions like complaining (voice), seeking redress and personal boycott (exit), taking legal action, and/or get engrossed in non-behavioural responses, where no action is taken, like in the case of Hirschman's (1970) loyalty-related response (Mason and Hines, 1973; Warland, Hirrmann and Willits, 1975; Gronhaug and Zaltman, 1981; Day, 1980; Day and Ladon, 1977). Along these lines, Singh (1988) suggested that customer responses may be categorised as either private, such as using negative wordof-mouth or exit; public, which involves using the voice option to seek redress while restraining one's self from taking action; or third-party response, which encompasses taking legal action or reporting the matter to a consumer agency.

In an attempt to understand and predict the factors that influence the choice of responses utilised by dissatisfied consumers, scholars have been concerned with uncovering positive correlations in relations to psychographic variables including values, personality, opinions and attitudes (Bearden and Masin, 1984); demographic variables including income, gender, marital status, age and education (Sujithamark and lam, 2005), and, to some extent, culture (Keng, Richmond and Han, 1995). Of all the variables studied within this research project, culture was the least investigated (Liu and McClure, 2001), thus, intensifying the justification for the need of the current study. Accordingly, this research project aims at investigating issues related to the differences in the cultural understanding of loyalty. This is undertaken in the current study through exploring dissatisfaction response styles of Anglo-Saxon Australian and international Asian Chinese tertiary students, as guided by their culturally defined perceptions and values.

\section{Literature Review}

\subsection{Benefits of Cultivating Service Loyalty}

Service loyalty has been defined as the "degree to which a customer exhibits repeat purchasing behaviour from a service provider, possesses a positive attitudinal disposition toward the provider, and considers using this provider when a need for this service arises' (Gremler and Brown, 1996). Cultivating the feeling of loyalty is just as important to services as it is important to products given the high risks that accompany them (Zeithaml, 1981). In addition, the intense interpersonal relationships between service providers and consumers give rise to a greater need and opportunities to create loyalty (Macintosh and Lockshin, 1998; Parasuraman, Zeithaml and Berry, 1985).

Customer loyalty is financially beneficial to the service provider as the overall costs of attracting a new customer, including the cost of advertising to attract new customers, cost of personal selling, setting up new accounts and cost of educating new customers of company procedures overrides the cost of retaining the existing one (Fornell and Wernerfelt, 1987; Peppers and Rogers, 1993). Research indicates that the average cost of attracting a new customer is five times higher than retaining an existing one (Barsky, 1994; Reicheld and Sasser, 1990).

Loyalty can be manifested in a number of ways: Repurchasing a service from the provider, being less price sensitive, increasing the number of frequency of purchase (Rust and Zahorik, 1993), or through influencing purchase decisions of other consumers (Rowley and Dawes, 2000). Furthermore, when faced with service dissatisfaction, loyal consumers are more likely to postpone exit. Instead, they voice their opinion or suffer in silence, in the hope that the situation will eventually improve (Hirschman, 1970). Loyal customers often use threats of exit as a tool to strengthen their complaint, which only further displays their commitment,

International Journal of Educational
Studies
Vol. 2 , No.2, pp. $44-52$
2019
DOI: $10.53935 / 2641-533 x . v 2 i 2.24$
"Corresponding Author: Linda Newsome
Email: linda.newsome@asu.edu
Funding: This study received no specific
financial support.
Article History:
Received: 21 January 2019
Revised: 15 February 2019
Accepted: 25 March 2019
Published: 17 April 2019
○ 2019 by the authors; licensee Academic
Publishing Group
Lut


and confirms the fact that they would try all means possible to improve the situation before resorting to exit (i.e., before switching to a different service provider) (Hirschman, 1970).

\subsection{Antecedents of Service Quality}

Various studies have previously been undertaken to identify and measure the dimensions of loyalty (Dick and Basu, 1994; Gremler and Brown, 1996; Jacoby and Chestnut, 1978; Pritchard, 1991; Sheth, 1968; Tucker, 1964). Such research indicated that loyalty is a form of behaviour directed toward particular brands over time, especially focusing on interpreting the observed behaviour of repeat purchasing (Jacoby and Chestnut, 1978; Tucker, 1964). This was seen as behavioural loyalty where the loyalty of the consumer was indicated by their behaviour over a period of time, precisely their engagement in repurchase of the service.

In the wake of the criticism of behavioural loyalty for lack of conceptual basis and narrow view, attitudinal loyalty, reflecting the degree to which customers are inclined to recommend a service provider to other customers, and to commit to re-patronise a preferred service provider (Gremler and Brown, 1996; Pritchard, 1991), was discussed.

Accordingly, based on a favourable attitude towards a service provider as reflected in their willingness to recommend the service provider, i.e., through positive word-of-mouth; and an intention to repurchase, consumers may develop the so-called preference loyalty. For the purpose of the current research, preference loyalty was identified as one of the dimensions of loyalty employed to measure loyalty of the participants.

In addition to behavioural and attitudinal loyalty, i.e., the preference dimension of loyalty; various researchers have argued for the existence of cognitive-type loyalty (Lee and Zeiss, 1980; Oliver, 1996), where consumers are believed to consciously evaluate the price/quality ratio of services when making a purchase decision (Fronell, 1992). Cognitive loyalty paves the way to the second identified dimension of loyalty, namely price indifference loyalty or price sensitivity, which was adopted in this study as a measure of loyalty.

Hirschman (1970) further proposed that loyalty will have an impact on the choice of response the dissatisfied consumer engages in. Such dissatisfaction response or complaining behaviour has been adopted in the current study as the third dimension of loyalty, with commitment being the fourth measurement. A customer will want to stay loyal when they are satisfied and have formed interpersonal bonds with their supplier. On the other hand, customers also stay loyal when they feel that they have to as they are pressured by high switching costs (Gremler and Brown, 1996). As such, satisfaction, switching costs and interpersonal bonds are antecedents of service loyalty. In other words, they represent factors that determine whether or not a customer becomes or remains a loyal patron (Anderson and Fornell, 1994; Gremler and Brown, 1996).

A consumer feels dissatisfied when the actual performance of the service is equal to or better than their expectations for that performance (Oliver, 1981). Satisfaction seems to be the most commonly accepted requirement as the foundation of customer loyalty (Anderson and Fornell, 1994; Bearden and Tell, 1983); however, disagreements continue as to whether satisfied customers are necessarily loyal customers. Even though dissatisfaction nearly guarantees switching, satisfaction does not ensure loyalty (Mittal and Lasser, 1998). Research indicate that customers reporting high levels of satisfaction still display a tendency to switch service suppliers, inferring that customer satisfaction may not be enough to create and maintain customer loyalty (Cronin and Steven, 1992; Fornell, 1992; Mittal and Lasser, 1998).

Switching cost is the cost involved in changing from one service provider to another (Porter, 1980), including psychological, physical and economic costs (Jackson, 1985). Such switching costs tend to be higher for services than for products (Gremler and Brown, 1996). Furthermore, consumers form interpersonal relationships with their service providers based on familiarity, care, friendship, and rapport or trust (Berry, 1983; Czepiel, 1990), which makes the termination of relationships psychologically hard for loyal customers. As such, it is possible that such interpersonal bonds are the reasons why some consumers remain loyal.

In order to keep a consumer satisfied, the service performance has to meet or exceed consumer's expectations, otherwise, it will result in consumer dissatisfaction (Oliver, 1981). Even though service organizations aspire to offer perfect services with no shortcomings, some service failures are unavoidable and unpredictable. As a matter of fact, service dissatisfactions are frequent, and as many as one in every five service experiences results in dissatisfaction (Day and Ash, 1979). According to Oliver (1981), if consumer dissatisfaction is left to linger, consumers will form negative attitudes, which damagingly influence repeat purchase intentions, service loyalty and word-of-mouth.

\begin{tabular}{l} 
International Journal of Educational \\
Studies \\
Vol. 2 , No.2, pp. $44-52$ \\
2019 \\
DOI: $10.53935 / 2641-533 x . v 2 i 2.24$ \\
'Corresponding Author: Linda Newsome \\
Email: linda.newsome@asu.edu \\
Funding: This study received no specific \\
financial support. \\
Article History: \\
Received: 21 January 2019 \\
Revised: 15 February 2019 \\
Accepted: 25 March 2019 \\
Published: 17 April 2019 \\
○) 2019 by the authors; licensee Academic \\
Publishing Group \\
\hline
\end{tabular}




\subsection{Service Dissatisfaction Response Styles}

In addition to identifying the response options available to dissatisfied consumers, it is also important to evaluate the reasons why consumers choose a particular response option. Generally, the type of response consumers engages in depend on market factors or industry characteristics (Hirschman, 1970), where lack of alternatives rules out exit and abundance of alternatives may increase chances or exit. Furthermore, seller and services factors such as complaint handling reputation (Anderson and Sullivan, 1993), service complexity, importance of purchase and expense will all impact on consumers' choice of post-purchase recovery. In addition, individual characteristics of the dissatisfied customers impact on their choice or response to postpurchase dissatisfaction (Hirschman, 1970). First, consumers' perceived probability that the complaint will successfully lead to desired consequences will influence their tendency to postpone exit (Day, 1980; Day and Landon, 1977; Hirschman, 1970), or use negative word-of-mouth, but rather engage in voicing a complaint.

Research indicates that complainers tend to value uniqueness and individuality and have a greater sense of independence than non-complainers (Morgansky and Buckley, 1981). It was further indicated that income, education and age positively related to public complaints, as individuals who complained publicly were usually younger, better educated and with high income levels (Day and Landon, 1977). Furthermore, consumers who do not speak up when dissatisfied are in fact members of particularly vulnerable groups in the marketplace, such as socio-economically disadvantaged immigrants (Andreason and Manning, 1990).

\subsection{Cultural Perceptions of Loyalty}

Research indicates that individuals' values, attitudes beliefs, self-concept, perceptions of others, and patterns of interactions with the environment are shaped by cultural meaning systems (Triandis, 1989). As such, it can be inferred that culture impacts response patterns to post-purchase dissatisfaction (Liu and McClure, 2001).

Culture is defined as the "collective programming of the mind which distinguishes the members of one group or category of people from those of another" (Hofstede, 1994). Furthermore, Hofstede (1980) proposed five independent dimensions of culture, namely: Power distance, uncertainty avoidance, individualism/collectivism, masculinity/femininity and short-term/long-term orientation (Hofstede, 1980; 1994). The collectivism vs. individualism dimension has been most useful to describe and compare cultures (Hofstede, 1980), and to predict the member's likely response to dissatisfaction, namely: Voice, private response or third-party responses (Singh, 1988).

Attitudes of collectivist culture members are shaped by their individual needs of belonging, fitting in, engaging in contextually appropriate actions, while maintaining social harmony and saving face of self and others (Hofstede, 1980; Liu and McClure, 2001; Watkins and Liu, 1996). Within collectivist cultures, members consider their friends and relatives as in-groups and everyone else, including service providers as out-groups. Personal approval of voice behaviour is lower in collectivist cultures than individualist cultures, and it is directly influenced by the perceived social approval of the voice behaviour. Collectivist cultures, in general, tend to value conformity and harmony (Newsome and Cooper, 2016), while confrontational voice is not acceptable, that is, complaining behaviour, in general, is discouraged (Triandis, 1989). Guided by such beliefs, collectivists do not tend to freely express emotions, especially negative ones, through third party or voice actions. In cases of dissatisfaction, they express emotions in private settings to in-groups (Liu and McClure, 2001; Markus and Kitayama, 1990).

According to Yang (1989), there are at least four basic Chinese cultural values that determine the way Chinese consumers handle dissatisfaction, namely: Social harmony, moderation, 'face' and the concept of Pao (reciprocity). As Chinese individuals desire to maintain social harmony in public, they are often reluctant to voice their dissatisfaction. The need to maintain 'face' in public also serves as a negative force for complaint behaviour, due to the fear of an unsatisfactory outcome with the complaint (Yang, 1989). Furthermore, public argument is seen as a face losing act which damages interpersonal harmony (Gao et al., 1996), The avoidance of confrontation and maintenance of social harmony provokes consumers to take more indirect modes of complaining behaviour or private action.

On the contrary, individualistic cultures are concerned with the attainment of personal goals, while their self-esteem depends on the ability to express self and validate internal defining attributes (Hofstede, 1980; Watkins and Liu, 1996). As such, they define in-groups as anyone that is equivalent to them in social class, race, beliefs, attitudes and values, which result in individualists forming many in-groups (Watkins and Liu,

International Journal of Educational
Studies
Vol. 2, No.2, pp. $44-52$
2019
DOI: 10.53935/2641-533x.v2i2.24
aCorresponding Author: Linda Newsome
Email: Linda.newsome@asu.edu
Funding: This study received no specific
financial support.
Article History:
Received: 21 January 2019
Revised: 15 February 2019
Accepted: 25 March 2019
Published: 17 April 2019
@ 2019 by the authors; licensee Academic
Publishing Group
| 47


1996). Due to such beliefs, members of individualist cultures are more inclined to voice their dissatisfaction through complaining publicly and engaging in third party responses to dissatisfaction than engage in private responses (Liu and McClure, 2001).

Tertiary education represents a service and students may experience dissatisfaction with both academic issues (such as, resources available, modes of instruction and delivery, pedagogy and course contents, ... etc.), as well as non-academic factors (including financial aid, quality of on-campus accommodation, campus attractiveness, availability of various services and facilities, ... etc.) (Roszkowski and Ricci, 2004). In the current study, international students from an Asian Chinese background represent the collectivist culture, and Australian students with an Anglo-Saxon background represent the individualist culture.

\section{Research Method}

A sample of 150 university students (75 Anglo-Saxon Australian students and 75 international Asian Chinese students) were surveyed via a self-completed questionnaire composed of a combination of openended and closed-ended questions relating to their demographics, proneness to loyalty and the likely response styles to service dissatisfaction. In addition, participants were given the chance to make additional related comments, thus, allowing for conclusions and generalizations to be made. Of the 150 respondents surveyed, forty four percent $(44 \%)$ were postgraduate students and fifty six percent $(56 \%)$ were undergraduate students. In addition, thirty six percent (36\%) have been studying for only one semester, thirty nine percent $(39 \%)$ have been studying for more than a semester but less than three (3) years, and twenty five percent (25\%) have been studying for more than three (3) years.

The survey questionnaire consisted of several sections, starting with a number of screening questions aimed at gathering more background information on the participants. This was followed by four key sections relating to commitment, brand preference, price indifference, and dissatisfaction response; all of which were employed as dimensions of loyalty. In addition, the last section features a critical incident question.

\section{Results}

The purpose of this research is to identify the likely impact that loyalty may have on the students' response to dissatisfaction. As such, four dimensions of loyalty were investigated, namely, commitment, preference loyalty (word-of-mouth communication and purchase intention), price sensitivity and response to service dissatisfaction.

The findings of this study indicated that there is a significant difference between the two surveyed groups, Anglo-Saxon Australian students and international Asian Chinese students, in terms of their levels of loyalty as well as the response options they engaged in after dissatisfaction situations. Anglo-Saxon Australian students were found to be more likely to complain publicly and directly to the service provider, whereas international Asian Chinese students were most likely to respond by complaining privately to their friends and relatives, or even do nothing. Such differences were found to be mostly attributable to differences in cultural values.

In view of the three dimensions of loyalty, namely commitment, preference and price sensitivity, AngloSaxon Australian students proved to be more loyal to their tertiary institutions. In comparison to international Asian Chinese students, Anglo-Saxon Australian students exhibited higher means of commitment and preference, while scoring a lower mean for price sensitivity. In regards to the 'third party' response to service dissatisfaction, both Anglo-Saxon Australian students and international Asian Chinese students were similar in their responses (with respective total mean scores of 3.25 and 3.28). Both groups were not keen on taking such drastic measures in case of dissatisfaction. Among the three likely dissatisfaction response styles previously discussed, third party was the least employed. Anglo-Saxon Australian students were less likely to write to a local newspaper, and report to a consumer agency to warn other students when compared to international Asian Chinese students.

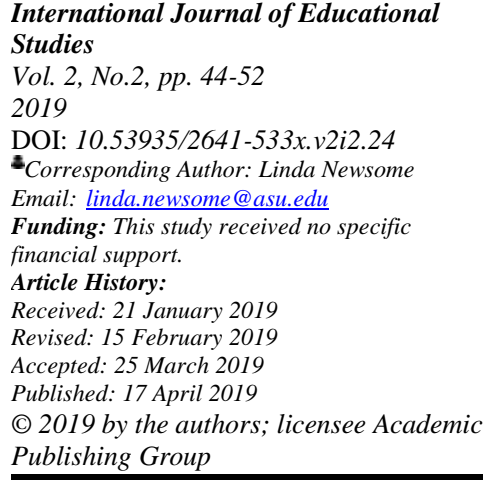


Table-1. Students' Response to Dissatisfaction

\begin{tabular}{l|c|c|c|c}
\hline Student Ethnic Background & Do Nothing & $\begin{array}{c}\text { Complain to Tertiary } \\
\text { Institution }\end{array}$ & $\begin{array}{c}\text { Complain to } \\
\text { Friends }\end{array}$ & Use Exit Option \\
\hline $\begin{array}{l}\text { Anglo-Saxon Australian } \\
\text { Students }\end{array}$ & 4 & 62 & 43 & 1 \\
\hline $\begin{array}{l}\text { International Asian Chinese } \\
\text { Students }\end{array}$ & 15 & 30 & 45 & 3 \\
\hline
\end{tabular}

As per Table 1 above, of the hundred and fifty (150) students surveyed, nineteen (19) students claimed that in case of dissatisfaction, they would choose to "do nothing". Interestingly, fifteen (15) out of the nineteen (19) respondents were international Asian Chinese students whereas only four (4) Anglo-Saxon Australian students agreed that they would take a non-active form of action. On the contrary, when asked if they would complain directly to the tertiary institution in case of dissatisfaction, over twice as many Anglo-Saxon Australian students (62) indicated that they would in fact take this form of action in comparison to thirty (30) international Asian Chinese students. Moreover, when comparing the frequency of students indicating that they would complain to their friends about their dissatisfaction, the results are somewhat similar with fortythree (43) Anglo-Saxon Australian and forty-five (45) international Asian Chinese students confirming that they would complain to their friends. Only four (4) out of the hundred and fifty (150) students indicated that they would use the exit option in case of dissatisfaction. Of these students, three (3) out of four (4) were international Asian Chinese students.

\section{Discussion}

5.1. The Relationship between Satisfaction and Loyalty

Some considerations should be kept in mind when analysing the results generated in the current study. First, the Chinese culture encourages less complaints which may partly explain their recorded higher average level of satisfaction. Secondly, Chinese students have lower expectations which may be more easily met. Due to the higher level of satisfaction, Chinese students seem to be more loyal consumers than Australian students.

The results in relation to the commitment factors, that is, the feeling of involvement and affiliation with the service provider and the resulting emotional bond (Mattila, 2004), indicate that there is no significant difference between Anglo-Saxon Australian and international Asian Chinese students. Even though research results suggest that Chinese students have a higher level of satisfaction, it is the Anglo-Saxon Australian students who are more likely to disseminate positive word-of-mouth. These results are consistent with Hofstede's (1980) characterization of collectivist and individual cultures.

The price sensitivity results indicate that the two groups are not significantly different in their sensitivity to price acceptance. Nevertheless, consideration should be given to the fact that Australian citizens have an opportunity for free education which they pay for later on in life, while international Asian Chinese students have to pay their tuition fees upfront. As such, price increases are more likely to impact on their decision to stay or to exit.

\subsection{Post-Purchase and Post-Consumption Dissatisfaction Response}

Results indicated that the most popular response to dissatisfaction among both groups of students is private response, with the greatest emphasis being placed on 'speaking to friends and relatives about the bad experience'. The second most favourite response to dissatisfaction is the 'voice response', with the greatest emphasis being 'going back immediately to complain' for the Anglo-Saxon Australian students, in comparison to 'don't forget the incident, and do something about it', being the most common voice response for the international Asian Chinese students. Both groups displayed a fairly similar tendency to take third party action.

It was further indicated that Anglo-Saxon Australian students, guided by their individualistic values, thrive on attaining personal goals, express themselves and validate their internal defining attributes (Hofstede, 1980; Watkins and Liu, 1996), are most likely to respond to dissatisfaction by directly complaining to the tertiary institution, followed by 'complaining to friends', as the second most favourable response. On the contrary, international Asian Chinese students showed the greatest tendency to complain to friends. Furthermore, Asian students were significantly more likely to respond with 'do nothing', and more likely to leave the institution as a consequence of dissatisfaction, when compared to Anglo-Saxon Australian students.

\author{
Academia
International Journal of Educational
Vol. 2 , No.2, pp. $44-52$
2019
DOI: $10.53935 / 2641-533 x . v 2 i 2.24$
Corresponding Author: Linda Newsome
Email: :inda.newsome@ asu.edu
Funding: This study received no specific
financial support.
Article History:
Received: 21 January 2019
Revised: 15 February 2019
Accepted: 25 March 2019
Published: 17 April 2019
() 2019 by the authors; licensee Academic
Publishing Group
| 49 \\ Academia
International Journal of Educational
Vol. 2 , No.2, pp. $44-52$
2019
DOI: $10.53935 / 2641-533 x . v 2 i 2.24$
Corresponding Author: Linda Newsome
Email: :inda.newsome@ asu.edu
Funding: This study received no specific
financial support.
Article History:
Received: 21 January 2019
Revised: 15 February 2019
Accepted: 25 March 2019
Published: 17 April 2019
() 2019 by the authors; licensee Academic
Publishing Group
| 49 \\ Academia
International Journal of Educational
Vol. 2 , No.2, pp. $44-52$
2019
DOI: $10.53935 / 2641-533 x . v 2 i 2.24$
Corresponding Author: Linda Newsome
Email: :inda.newsome@ asu.edu
Funding: This study received no specific
financial support.
Article History:
Received: 21 January 2019
Revised: 15 February 2019
Accepted: 25 March 2019
Published: 17 April 2019
() 2019 by the authors; licensee Academic
Publishing Group
| 49 \\ Academia
International Journal of Educational
Vol. 2 , No.2, pp. $44-52$
2019
DOI: $10.53935 / 2641-533 x . v 2 i 2.24$
Corresponding Author: Linda Newsome
Email: :inda.newsome@ asu.edu
Funding: This study received no specific
financial support.
Article History:
Received: 21 January 2019
Revised: 15 February 2019
Accepted: 25 March 2019
Published: 17 April 2019
() 2019 by the authors; licensee Academic
Publishing Group
| 49 \\ Academia
International Journal of Educational
Vol. 2 , No.2, pp. $44-52$
2019
DOI: $10.53935 / 2641-533 x . v 2 i 2.24$
Corresponding Author: Linda Newsome
Email: :inda.newsome@ asu.edu
Funding: This study received no specific
financial support.
Article History:
Received: 21 January 2019
Revised: 15 February 2019
Accepted: 25 March 2019
Published: 17 April 2019
() 2019 by the authors; licensee Academic
Publishing Group
| 49 \\ Academia
International Journal of Educational
Vol. 2 , No.2, pp. $44-52$
2019
DOI: $10.53935 / 2641-533 x . v 2 i 2.24$
Corresponding Author: Linda Newsome
Email: :inda.newsome@ asu.edu
Funding: This study received no specific
financial support.
Article History:
Received: 21 January 2019
Revised: 15 February 2019
Accepted: 25 March 2019
Published: 17 April 2019
() 2019 by the authors; licensee Academic
Publishing Group
| 49 \\ Academia
International Journal of Educational
Vol. 2 , No.2, pp. $44-52$
2019
DOI: $10.53935 / 2641-533 x . v 2 i 2.24$
Corresponding Author: Linda Newsome
Email: :inda.newsome@ asu.edu
Funding: This study received no specific
financial support.
Article History:
Received: 21 January 2019
Revised: 15 February 2019
Accepted: 25 March 2019
Published: 17 April 2019
() 2019 by the authors; licensee Academic
Publishing Group
| 49 \\ Academia
International Journal of Educational
Vol. 2 , No.2, pp. $44-52$
2019
DOI: $10.53935 / 2641-533 x . v 2 i 2.24$
Corresponding Author: Linda Newsome
Email: :inda.newsome@ asu.edu
Funding: This study received no specific
financial support.
Article History:
Received: 21 January 2019
Revised: 15 February 2019
Accepted: 25 March 2019
Published: 17 April 2019
() 2019 by the authors; licensee Academic
Publishing Group
| 49 \\ Academia
International Journal of Educational
Vol. 2 , No.2, pp. $44-52$
2019
DOI: $10.53935 / 2641-533 x . v 2 i 2.24$
Corresponding Author: Linda Newsome
Email: :inda.newsome@ asu.edu
Funding: This study received no specific
financial support.
Article History:
Received: 21 January 2019
Revised: 15 February 2019
Accepted: 25 March 2019
Published: 17 April 2019
() 2019 by the authors; licensee Academic
Publishing Group
| 49 \\ Academia
International Journal of Educational
Vol. 2 , No.2, pp. $44-52$
2019
DOI: $10.53935 / 2641-533 x . v 2 i 2.24$
Corresponding Author: Linda Newsome
Email: :inda.newsome@ asu.edu
Funding: This study received no specific
financial support.
Article History:
Received: 21 January 2019
Revised: 15 February 2019
Accepted: 25 March 2019
Published: 17 April 2019
() 2019 by the authors; licensee Academic
Publishing Group
| 49 \\ Academia
International Journal of Educational
Vol. 2 , No.2, pp. $44-52$
2019
DOI: $10.53935 / 2641-533 x . v 2 i 2.24$
Corresponding Author: Linda Newsome
Email: :inda.newsome@ asu.edu
Funding: This study received no specific
financial support.
Article History:
Received: 21 January 2019
Revised: 15 February 2019
Accepted: 25 March 2019
Published: 17 April 2019
() 2019 by the authors; licensee Academic
Publishing Group
| 49 \\ Academia
International Journal of Educational
Vol. 2 , No.2, pp. $44-52$
2019
DOI: $10.53935 / 2641-533 x . v 2 i 2.24$
Corresponding Author: Linda Newsome
Email: :inda.newsome@ asu.edu
Funding: This study received no specific
financial support.
Article History:
Received: 21 January 2019
Revised: 15 February 2019
Accepted: 25 March 2019
Published: 17 April 2019
() 2019 by the authors; licensee Academic
Publishing Group
| 49 \\ 49
}


Even though research findings indicate that international Asian Chinese students enjoy a higher level of satisfaction, Anglo-Saxon Australian students exhibited somewhat higher levels of commitment, positive word-of-mouth communication and purchase intention, combined with lower levels of price sensitivity. An overall generalization can be made in that Anglo-Saxon Australian students are somewhat more loyal than international Asian Chinese students. This somewhat contradicts the previous suggestion that Chinese students, who were identified to have a higher level of satisfaction, are not more loyal to their relative tertiary institutions. It is also possible that the Chinese students are not necessarily more satisfied than the Australian students, but rather have lower expectations and a higher sense of avoidance for public complaining (Yang, 1989).

Accordingly, this study supports previous research results that suggest that even though satisfaction is an important factor for loyalty, mere satisfaction may not be enough to create and maintain customer loyalty satisfaction (Anderson and Fornell, 1994; Mittal and Lasser, 1998). After evaluating the two groups' modes of likely response to service dissatisfaction, it seems that previous research findings, indicating that loyal consumers are more likely to complain to the service provider than 'do nothing' or 'switch service providers' (Hirschman, 1970), are also confirmed by the current research outcome. A possible explanation is that loyal consumers are more invested and have a higher level of caring about the service provider. As such, when faced with dissatisfaction, they do not just abandon or switch providers, but rather voice their dissatisfaction to the service provider through complaining and demanding rectifications. It is for this reason, among others, that leaderships of tertiary educational institutions should encourage voicing of complaints, and, in turn, make every possible attempt to resolve them to mutual satisfaction and reciprocated benefit.

\section{Conclusion}

A main issue that has been identified in the current study is that loyalty has an impact on the Anglo-Saxon Australian and the international Asian Chinese students' post-purchase recovery in the context of tertiary education. Measured through commitment, word-of-mouth communication, purchase intention, price indifference, and dissatisfaction response; current findings indicated that Anglo-Saxon Australian students exhibit higher levels of loyalty.

The current study has given rise to numerous avenues for further research, including the undertaking of the same research on a larger scale. To further test the validity of the research findings of the current study, the researcher may recruit students from several tertiary institutions around Australia to get a better representation of both the international Asian Chinese and the Anglo-Saxon Australian students. In addition, to further test the predictions of the current study, research is warranted in terms of surveying and comparing Chinese students attending Chinese universities and Australian students attending Australian universities. Furthermore, it would be interesting to undertake multicultural research aimed at discovering how other cultures, besides Chinese and Australian, would respond to dissatisfaction with educational services.

\section{References}

Anderson, E. W. \& Fornell, C. (1994). A customer satisfaction research prospectus, in R. T. Rust and R. L. Oliver (Eds.), Service Quality: New Direction in Theory and Practice. Thousand Oaks: Sage Publications, Inc. pp: 241-268.

Anderson, E. W. \& Sullivan, M. W. (1993). The antecedents and consequences of customer satisfaction for firms. Marketing Science, Spring, 12(2): 125-143.

Andreason, A. R. \& Manning, J. (1990). The dissatisfaction and complaint behaviour of vulnerable customers. Journal of Consumer Satisfaction, Dissatisfaction and Complaining Behaviour, 3(1): 12-20.

Barsky, J. (1994). World-class customer satisfaction. Illinois: Irwin Professional Publishing.

Bearden, W. \& Mason, J. (1984). An investigation of influences on consumer complaint reports. Advances in Consumer Research, 11(1): 490-495.

Bearden, W. O. \& Tell, J. E. (1983). Selected determents of customer satisfaction and complaint reports. Journal of Marketing Research, 20(1): 21-28.

Berry, L. L. (1983). Relationship marketing, in L. L. Berry, G. L. Shostock and G. D. Upah (Eds.), Emerging Perspectives on Service Marketing. Chicago: American Marketing Association. pp: 25-28.

Cronin, J. J. J. \& Steven, A. T. (1992). Measuring service quality: A re-examination and extension. Journal of Marketing, 56(3): 55-68.

Czepiel, J. A. (1990). Managing relationships with customers: A differentiation philosophy of marketing, in D. E. Bowen, R. B. Chase and T. G. Cummings (Eds.), Service Management Effectiveness. San Francisco: JosseyBass Publishers. pp: 299-323. 
Day, R. L. (1980). Research perspectives in consumer complaining behaviour, in C. W. Lamb and P. M. Dunne (Eds.), Theoretical Developments in Marketing. Chicago: American Marketing Association. pp: 211-215.

Day, R. L. \& Ash, S. B. (1979). Selected determents of customer satisfaction and complaint reports. Journal of Marketing Research, 20(1): 21-28.

Day, R. L. \& Landon, E. L. J. (1977). Toward a theory of consumer complaining behaviour, in A. Woodside, J. Sheth and P. Bennett (Eds.), Consumer and Industrial Buying Behaviour. Amsterdam: North-Holland Publishing Company.

Dick, A. S. \& Basu, K. (1994). Customer loyalty: Toward an integrated conceptual framework. Journal of the Academy of Marketing Science, 22(2): 99-113.

Fornell, C. (1992). A national consumer satisfaction barometer: The Swedish experience. Journal of Marketing, 56(1): 621.

Fornell, C. \& Wernerfelt, B. (1987). Recognising cross-cultural differences in consumer complaint behaviour and intentions: An empirical examination. Journal of Consumer Marketing, 18(1): 54-74.

Gao, G., Tommey, S. T. \& Gudykunst, W. (1996). Consumer complaint behaviour toward hotel restaurant service. International Journal of Contemporary Hospitality Management, 15(5): 283-289.

Gremler, D. D. \& Brown, S. W. (1996). Service loyalty: Its nature, importance and implications. International Service Quality Association, USA: Business Research Institute.

Gronhaung, K. \& Zaltman, G. (1981). Complainers and non-complainers revised: Another look at the data. Advances in Consumer Research, 1(2): 121-134.

Helou, M. (2005). Ethnic marketing, multi-culturalism and consumer purchase behaviour: Issues of cultural identity. International Journal of Diversity in Organizations, Communities and Nations, 5(1): 181-184.

Helou, M. \& Caddy, I. (2007). Market model innovations in the contextualization of consumer behaviour and service recovery: The case of China. Innovation Marketing, 3(1): 36-43.

Hirschman, A. O. (1970). Exit, voice and loyalty: Responses to decline in firms, organizations and states. London: Harvard University Press.

Jackson, B. (1985). Winning and keeping industrial customers: The dynamics of customer relationships. Lexington: Lexington Books.

Jacoby, J. \& Chestnut, R. W. (1978). Brand loyalty: Management and management. New York: John Wiley \& Sons.

Keng, K. A., Richmond, D. \& Han, S. (1995). Determinants of consumer complaint: A study of Singapore consumer. Journal of International Consumer Marketing, 8(2): 59-76.

Liu, R. R. \& McClure, P. (2001). Recognizing cross-cultural differences in consumer complaint behaviour and intentions: An empirical examination. Journal of Consumer Marketing, 18(1): 54-74.

Macintosh, G. \& Lockshin, L. S. (1998). Retail relationships and store loyalty: A multilevel perspective. International Journal of Research in Marketing, 14(5): 487-498.

Markus, H. \& Kitayama, S. (1990). Culture and self: Implications for cognition, emotion and motivation. Psychological Review, 98(2): 224-253.

Mason, J. B. \& Himes, S. H. J. (1973). An exploratory behavioural and socio-economic profile of consumer action about dissatisfaction with selected household appliances. Journal of Consumer Affairs, 7(2): 121-127.

Mittal, B. \& Lasser, W. M. (1998). Why do consumers switch? The dynamics of satisfaction versus loyalty. The Journal of Service Marketing, 12(3): 177-194.

Newsome, L. \& Cooper, P. (2016). International students' cultural and social experiences in a British University: Such a hard life [it] is here. Journal of International Students, 6(1): 195-215.

Oliver, R. L. (1996). Satisfaction: A behavioural perspective on the consumer. New York: McGraw Hill.

Parasuraman, A., Zeithaml, V. A. \& Berry, L. L. (1985). A conceptual model of service quality and its implications for future research. Journal of Marketing, 49(4): 41-50.

Peppers, D. \& Rogers, M. (1993). The one to one relationship: Building relationships one consumer at a time. Doubleday: New York.

Porter, M. (1980). Competitive strategy. New York: Free Press.

Pritchard, M. P. (1991). Development of the psychological commitment instrument (PCI) for measuring travel service loyalty. Doctoral Dissertation, University of Oregon.

Studies 2 , No.2, pp. 44-52

2019

DOI: $10.53935 / 2641-533 x . v 2 i 2.24$

Corresponding Author: Linda Newsome

Email: linda.newsome@asu.edu

Funding: This study received no specific

financial support.

financial support:

Article History:

Received: 21 January 2019

Revised: 15 February 2019

Accepted: 25 March 2019

(1) 2019 by the authors; licensee Academic Publishing Group

Reicheld, F. \& Sasser, W. E. J. (1990). Zero defections: Quality comes to services. Harvard Business Review, 68(5): 105-111.

Roszkowski, M. J. \& Ricci, R. (2004). Measurement of importance in a student satisfaction questionnaire: Comparison of the direct and indirect methods for establishing attribute importance. Journal of College Student Retention, 6(3): 251-271.

Rowley, J. \& Dawes, J. (2000). Disloyalty: A closer look at non-loyals. Journal of Consumer Marketing, 17(6): 538-549.

Rust, R. T. \& Zahorik, A. J. (1993). Customer satisfaction, customer retention, and market share. Journal of Retailing, 69(2): 193-215.

Sheth, J. N. (1968). A factor analytic model of brand loyalty. Journal of Marketing Research, 5(4): 395-404. 
Singh, J. (1988). Consumer complaint intentions and behaviour: Definitional and taxonomical issues. Journal of Marketing, 52(1): 93-107.

Sujithamrak, S. \& Lam, T. (2005). Relationship between complaint behaviour and demographic characteristics: A study of hotel restaurants' patrons. Asia Pacific Journal of Tourism Research, 10(3): 289-307.

Triandis, H. C. (1989). The self and social behaviour in differing cultural contexts. Psychological Review, 96(3): 506520.

Tucker, W. T. (1964). The development of brand loyalty. Journal of Marketing Research, 1(3): 32-35.

Warland, R., Herrmann, R. \& Willits, J. (1975). Dissatisfied consumer: Who gets upset and who takes action. Journal of Consumer Affairs, 9(2): 148-163.

Watkins, H. S. \& Liu, R. (1996). Collectivism, individualism and in-group membership: Implications for consumer complaining behaviour in multinational contexts. Journal of International Consumer Marketing, 8(3): 69-96.

Yang, C. F. (1989). Differences in 'cultural values' and effects on responses to marketing stimuli: A cross cultural study between Australians and Chinese from the people's Republic of China. European Journal of Marketing, 32(9/10): 843-867.

Zeithaml, V. (1981). How consumer evaluation processes differ between good and service. The Marketing of Services, Conference Proceedings, Chicago. pp: 186-190.

International Journal of Educational

$$
\text { Studies }
$$

Vol. 2, No.2, pp. 44-52

2019

DOI: $10.53935 / 2641-533 x . v 2 i 2.24$

Corresponding Author: Linda Newsome

Email: linda.newsome@asu.edu.

Funding: This study received no specific

financial support.

Article History:

Article History:
Received: 21 January 2019

Received: 21 January 2019

Revised: 15 February 2019

Accepted: 25 March 2019

(C) 2019 by the authors; licensee Academic

Publishing Group 